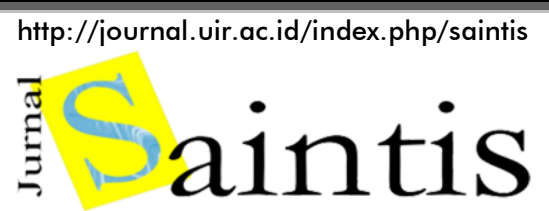

ISSN (Print)

$: 1410-7783$

ISSN (Online)

2580-7110

Volume 20 Nomor 01, Month 2020 : 35-46

\title{
Structural Failure Analysis of Building E ITERA Due to The Pounding Effect with Non-Linear Time History
}

\author{
Nugraha Bintang Wirawan ${ }^{1, *}$, Siska Apriwelni ${ }^{1}$ \\ ${ }^{1}$ Civil Engineering, Institut Teknologi Sumatera, Jl. Terusan Ryacudu, Way Huwi, Lampung Selatan, Indonesia
}

\author{
* Corresponding author: bintangwirawan@si.itera.ac.id \\ Tel.: +62-81383666087; Fax.: - \\ Received: 14 April 2020; Revised: 26 April 2020; Accepted: 28 April 2020. \\ DOI: 10.25299/saintis.2020.vol20(01).4832
}

\section{Abstract}

Lampung, a province where Institut Teknologi Sumatera (ITERA) is located, is an area that has a high level of seismicity. This research takes a case study of the Building E ITERA which has a dilatation building concept. Due to dilatation, inter-buildings have the risk of collisions because of earthquake loads. The purpose of this study is to determine the value of joint displacement in adjacent buildings when given a dynamic load of Time History and determine whether the adjacent buildings experience a pounding effect. A Time History earthquake load data that has been matched with the Lampung region response spectrum by software is applied to the model of Building E. Building $\mathrm{E}$ is modeled according to the as built drawing data and the results of field checking. Structure is analyzed using software. The results of the study showed that the structure of the Building E which was loaded by Loma Prieta earthquake that has been matched would experience inter-building collisions. Further research using earthquake record data taken in areas within certain radius from ITERA is need to be conducted to obtain more accurate results.

Keywords: Displacement, Matching, Pounding Effect, Response Spectrum, Time History

\section{INTRODUCTION}

Infrastructure development in Indonesia is increasing rapidly nowadays, such as buildings. As a result, land availability is decreasing hence buildings are built vertically and closely spaced. When earthquake occurs at adjacent building, it can potentially experience collisions if the distance between buildings is smaller than the actual maximum vertical displacement.

Building $\mathrm{E}$ is an example of infrastructure that was built close at Institut Teknologi Sumatera which is used for education. This building was designed using earthquake standard [1]. The concept of dilatation is used in this building, which consists of 3 separate buildings close to each other. Structures with dilatation are vulnerable to collisions between buildings due to dynamic loads that can lead to structural failure.

Dynamic analysis can be performed on the design of earthquake resistant structures if more accurate results are needed for earthquake forces applied on the structure, as well as to determine the structural response due to earthquake loads. Analysis can be performed either elastic or inelastic. Elastic analysis can be divided into two, namely Time History Modal Analysis and Response Spectrum
Analysis. In Time History analysis required earthquake acceleration data, whereas the analysis of the Response Spectrum required data from the Design Spectra so that the maximum response of each mode shape can be obtained. This elastic dynamic analysis is done by direct integration where this method is widely used because it is simpler [2].

In this study, structural behavior is analyzed in the form of structural displacement due to dynamic time history loads which has been carried out matching process with design response spectrum of Building E ITERA.

\section{Research Purposes}

This research aims to :

1. Analyze the structural failure that will occur due to non-linear time history earthquake load.

2. Determine whether the adjacent building at Building E ITERA experience pounding.

\section{METHODOLOGY}

\section{Flow Chart}

The research flow chart can be seen in Figure 1. 


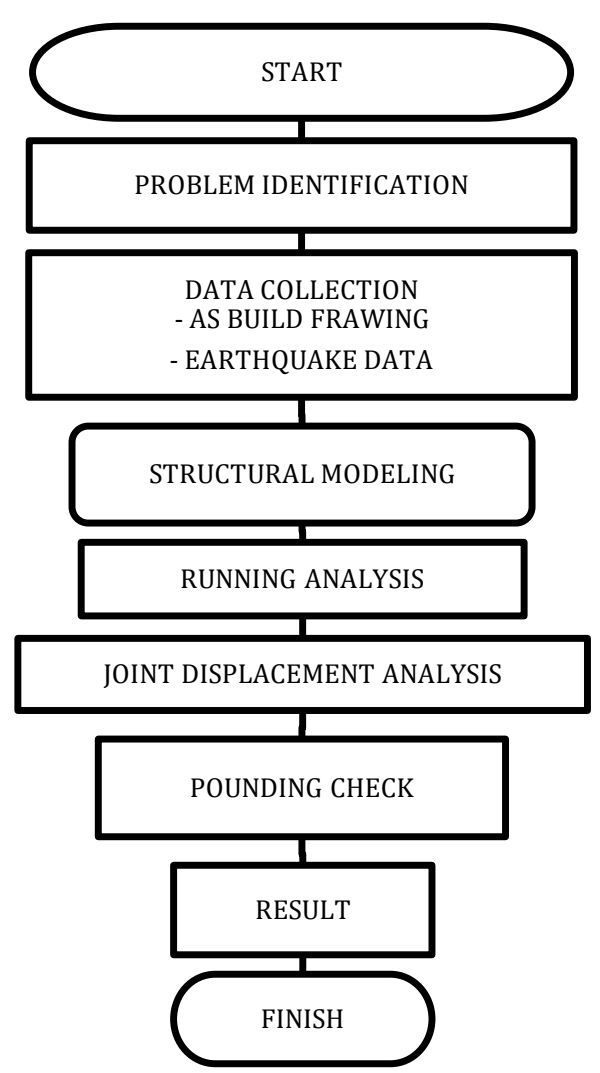

Figure 1. Flow Chart

Structural modelling by software can be illustrated in Figure 2.

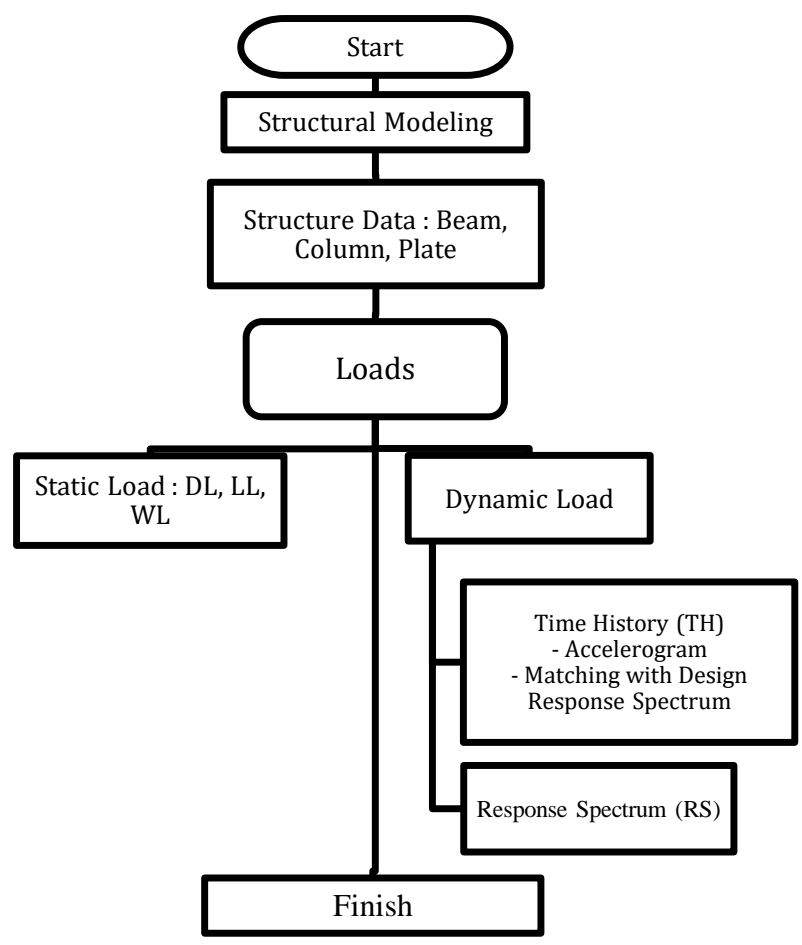

Figure 2. Structural Modeling Flow Chart

\section{Problem Identification}

Building E Institut Teknologi Sumatera has a basement because the field conditions have significant land contour differences. This building has a dilatation concept, where there are three buildings of different sizes. The two main buildings are used as lecture halls and a small building as a link between buildings. The concept of dilatation can be seen from the presence of cracks in the connecting column between adjacent buildings as in Figure 3 .

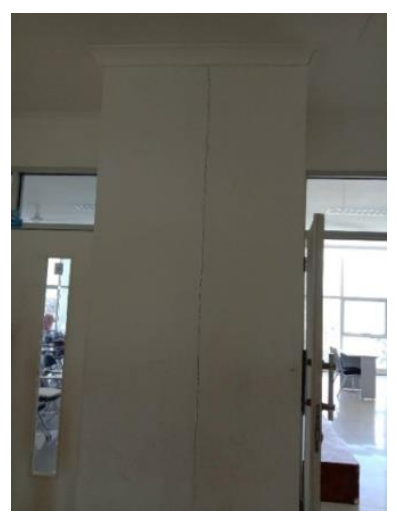

Figure 3. Cracks in Building E

\section{Data Collection}

The data used in this research are as built drawings of Building E ITERA and earthquake data. The earthquake data used are design response spectrum data and time history The Loma Prieta earthquake data.

\section{Structural Modeling}

Structural modeling in this study uses structural analysis software. The Building E ITERA is modeled using a reinforced concrete system and open 3D frame with the dimensions of the structure of columns, beams and plates in accordance with the as built drawing. The data used as a reference in modeling in this study are:
1. Building Function
: Lecture Room
2. Soil Type
3. Building Location
(Educational Facilities)
4. Number of Floors
: Medium (SD)
: South Lampung
: 5 (including basement and roof floor)
5. Height of Each Floor : 4,2 meter
6. Roof Floor Height : 3,0 meter
7. Concrete quality ( $\left.\mathrm{fc}^{\prime}\right): 25 \mathrm{MPa}$
8. Elastic Modulus : $23500 \mathrm{MPa}$

Preliminary dimensions of Building E can be seen in Table 1. 
Table 1. Structural Dimensions of Building E

\begin{tabular}{|c|c|c|c|}
\hline \multicolumn{2}{|c|}{$\begin{array}{l}\text { Structural } \\
\text { Element }\end{array}$} & $\begin{array}{l}\text { Dimensi } \\
\text { on (mm) }\end{array}$ & $\begin{array}{c}\text { Reinforcemen } \\
t(\mathbf{m m})\end{array}$ \\
\hline \multirow{2}{*}{$\begin{array}{c}\text { Colum } \\
\mathrm{n}\end{array}$} & K1 & $\begin{array}{c}500 \mathrm{x} \\
500\end{array}$ & 4D22 \\
\hline & K3 & $\begin{array}{c}500 x \\
500\end{array}$ & 4D19 \\
\hline \multirow{4}{*}{ Beam } & $\begin{array}{l}\text { Main } \\
\text { Beam } 1\end{array}$ & $\begin{array}{c}350 \mathrm{x} \\
700\end{array}$ & \\
\hline & $\begin{array}{l}\text { Main } \\
\text { Beam } 2\end{array}$ & $\begin{array}{c}250 x \\
500\end{array}$ & \\
\hline & Joist 1 & $\begin{array}{c}200 x \\
400\end{array}$ & \\
\hline & Joist 2 & $\begin{array}{c}200 x \\
300\end{array}$ & \\
\hline Floor & P1 & 120 & \\
\hline
\end{tabular}

Building E ITERA is modeled as in Figure 4.
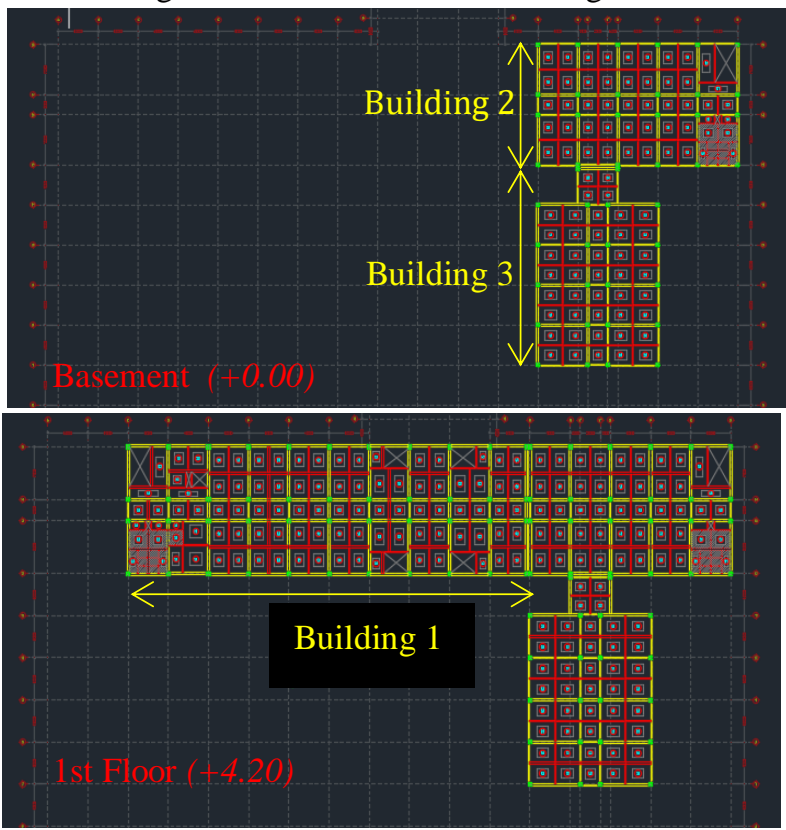

Figure 4. Separation of Building E

Separation of buildings is carried out in accordance with adjacent columns between buildings. Building 2 and Building 3 have a total height of $0 \mathrm{~m}$ to $15.6 \mathrm{~m}$ and Building 1 has a height of $4.2 \mathrm{~m}$ to $15.6 \mathrm{~m}$.

\section{Loads}

The loading carried out in this modeling includes the load on the plate that are dead load and live load, wind load and earthquake load.

1) Floor Load

The load that is added into the plate is SIDL (Super Imposed Dead Load) and live load according to code [3] and [4]. Life load used is 2.4 $\mathrm{kN} / \mathrm{m} 2$ for offices and $100 \mathrm{~kg} / \mathrm{m}^{2}$ for roof life load. SIDL load used is equal to $48 \mathrm{~kg} / \mathrm{m}^{2}$.
2) Wind Load

The loaded wind load has 4 directions. Winds that work in the positive $\mathrm{x}$ direction $(\mathrm{WX}+$ ), winds that work in the negative $\mathrm{x}$ direction (WX), winds that work in the positive y direction (WY+), and winds that work in the negative $y$ direction (WY-). This wind load works on each side of the building structure and the wind load used is $40 \mathrm{~kg} / \mathrm{m}^{2}$.

In wind load modeling, for each wind it is assumed that there are compressive and suction winds that work perpendicular to the fields being reviewed. The wind coefficients regulated in [3] are as in Figure 5.

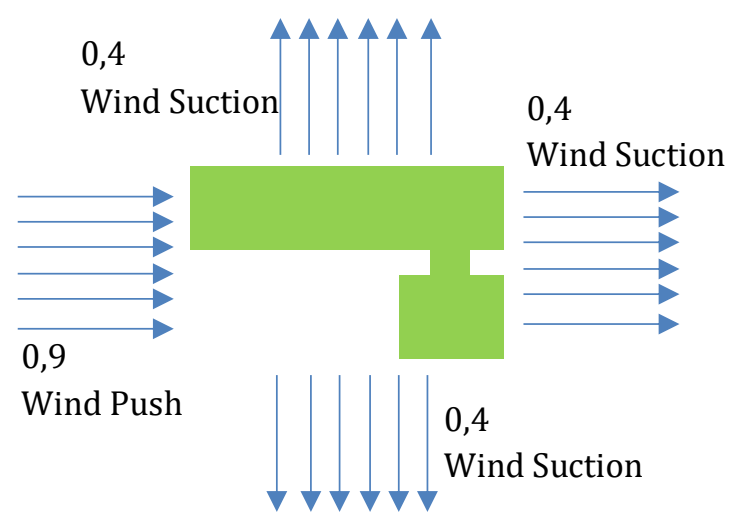

Figure 5. Wind coefficient

The coefficient also applies to the direction of each positive or negative wind direction acting on the structure. In the modeling of wind loads, for each wind load it is assumed that there are compressive and suction winds that work perpendicular to the fields being reviewed. The number of the suction and blowing wind acting on the plane of the structure is determined by multiplying the wind load by the wind coefficient.

3) Earthquake Load

a. Response Spectrum

Response Spectrum is the maximum response of the mass of Single Degree of Freedom structure both acceleration (Sa), velocity (Sv), and displacement $(\mathrm{Sd})$ to the period of the structure based on specific damping and earthquake ratios [5]. According to [1], for determining the spectral response of $\mathrm{MCE}_{\mathrm{R}}$ earthquake acceleration at ground level, a seismic amplification factor is needed at a period of 0.2 seconds and a period of 1 second with a probability of 2 percent exceeding in 50 years and expressed in decimal numbers to acceleration due to gravity. Amplification factors include vibration amplification factors related to acceleration in short period (Fa) vibrations and amplification factors related to acceleration that represent vibrations for 1 second period (Fv). The parameters of the acceleration response spectrum in the short period $\left(\mathrm{S}_{\mathrm{MS}}\right)$ and 1 second period $\left(\mathrm{S}_{\mathrm{M} 1}\right)$ adjusted for the 
influence of the site classification, must be determined by the following formulation:

$$
\begin{aligned}
& S_{M S}=F_{a} S_{s} \\
& S_{M 1}=F_{v} S_{1}
\end{aligned}
$$

Note :

Ss = Parameter of earthquake acceleration response spectrum $\mathrm{MCE}_{\mathrm{R}}$ mapped for short period.

$\mathrm{S}_{1}=$ Parameter of earthquake acceleration response spectrum $\mathrm{MCE}_{\mathrm{R}}$ mapped for 1 second period.

In determining the value of $\mathrm{S}_{\mathrm{s}}$ and $\mathrm{S}_{1}$ can be seen based on Figure 6 and Figure 7 as follows :

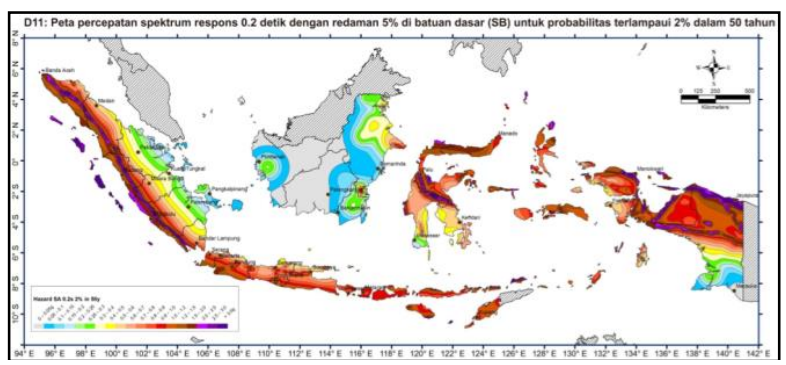

Figure 6. Ss map [6]

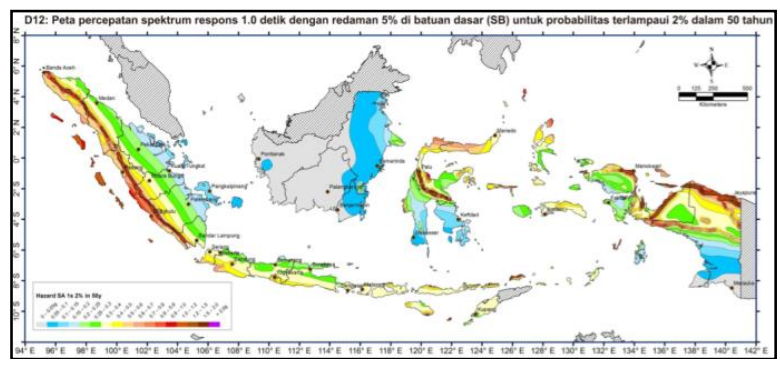

Figure 7. $S_{1}$ map [6]

To determine the site coefficients Fa and Fv, following table is used :

\begin{tabular}{|c|c|c|c|c|c|}
\hline \multirow[t]{3}{*}{$\begin{array}{l}\text { Site } \\
\text { Class }\end{array}$} & \multicolumn{5}{|c|}{$\begin{array}{c}\text { Earthquake spectral response acceleration } \\
\text { parameters }\left(M C E_{R}\right) \text { mapped at short } \\
\text { periods, } T=0.2 \text { seconds, } S \text { s }\end{array}$} \\
\hline & Ss $\leq$ & Ss $=$ & Ss $=$ & $\mathrm{Ss}=1$ & Ss $\geq$ \\
\hline & 0,25 & 0,5 & 0,75 & & 1,25 \\
\hline SA & 0,8 & 0,8 & 0,8 & 0,8 & 0,8 \\
\hline SB & 1,0 & 1,0 & 1,0 & 1,0 & 1,0 \\
\hline SC & 1,2 & 1,2 & 1,1 & 1,0 & 1,0 \\
\hline SD & 1,6 & 1,4 & 1,2 & 1,1 & 1,0 \\
\hline SE & 2,5 & 1,7 & 1,2 & 0,9 & 0,9 \\
\hline SF & & & $\mathrm{SS}^{\mathrm{b}}$ & & \\
\hline
\end{tabular}

Table 2. Site Coefficient, Fa [1]

Table 3. Koefisien situs, Fv [1]

\begin{tabular}{cccccc}
\hline $\begin{array}{c}\text { Site } \\
\text { Class }\end{array}$ & \multicolumn{2}{c}{$\begin{array}{c}\text { Earthquake spectral response acceleration } \\
\text { parameters (MCE }\end{array}$} \\
& \multicolumn{5}{c}{$\begin{array}{c}\text { mapped at } 1 \text { second } \\
\text { period, } \text { S }_{\mathbf{1}}\end{array}$} \\
\hline & Ss $\leq$ & Ss $=$ & Ss $=$ & Ss $=1$ & Ss $\geq$ \\
& 0,25 & 0,5 & 0,3 & & 1,25 \\
\hline SA & 0,8 & 0,8 & 0,8 & 0,8 & 0,8 \\
\hline
\end{tabular}

\begin{tabular}{cccccc}
\hline SB & 1,0 & 1,0 & 1,0 & 1,0 & 1,0 \\
\hline SC & 1,7 & 1,6 & 1,5 & 1,0 & 1,3 \\
\hline SD & 2,4 & 2 & 1,8 & 1,1 & 1,5 \\
\hline SE & 3,5 & 3,2 & 2,8 & 0,9 & 2,4 \\
\hline SF & \multicolumn{5}{c}{ SS } \\
\hline
\end{tabular}

The parameters of the design spectrum acceleration for the short period $\left(\mathrm{S}_{\mathrm{DS}}\right)$ and the 1 second period $\left(S_{D 1}\right)$ are calculated using the following equation:

$$
\begin{aligned}
& \mathrm{S}_{\mathrm{DS}}=2 / 3 \mathrm{~S}_{\mathrm{MS}} \\
& \mathrm{S}_{\mathrm{D} 1}=2 / 3 \mathrm{~S}_{\mathrm{M} 1}
\end{aligned}
$$

For the purposes of analysis, an acceleration design response spectrum (Sa) must be made corresponding to local soil conditions, with the following Sa equation:

1) For period less than $T_{0}$, Sa is determined by equation :

$$
\mathrm{Sa}=\mathrm{S}_{\mathrm{DS}}\left(0,4+0,6 \mathrm{~T} / \mathrm{T}_{0}\right)
$$

2) For period $T_{0} \leq T \leq T_{s}$, Sa is the same as $S_{D S}$

3) For period $T>T_{0}$, Sa is determined by equation :

$$
\mathrm{Sa}=\mathrm{S}_{\mathrm{D} 1} / \mathrm{T}
$$

$\mathrm{T}_{0}$ dan $\mathrm{T}_{\mathrm{s}}$ values are calculated by equation :

$$
\begin{aligned}
& \mathrm{T}_{0}=0,2 \cdot \mathrm{S}_{\mathrm{D} 1} / \mathrm{S}_{\mathrm{DS}} \\
& \mathrm{T}_{\mathrm{s}}=\mathrm{S}_{\mathrm{D} 1} / \mathrm{S}_{\mathrm{DS}}
\end{aligned}
$$

Data taken :
- Location
: Building E ITERA
Coordinate Lat. $\quad$ : -5.35941
Coordinate Long. : : 105.31149
- Soil Classification : Class D

From these data, the values of $\mathrm{Ss}, \mathrm{S}_{1}, \mathrm{Fa}, \mathrm{FV}, \mathrm{S}_{\mathrm{DS}}$, and $S_{\mathrm{D} 1}$ are as follows :

$$
\begin{array}{lll}
\text { Ss } & =0.718 \\
\mathrm{~S}_{1} & =0.311 \\
\mathrm{Fa} & =1.2264 \\
\mathrm{FV} & =1.779 \\
\mathrm{~S}_{\text {D1 }} & =0.5870 \\
\mathrm{~S}_{\text {DS }} & =0.3688
\end{array}
$$

Based on the results using the data above, response spectrum can be obtained as in Figure 8.

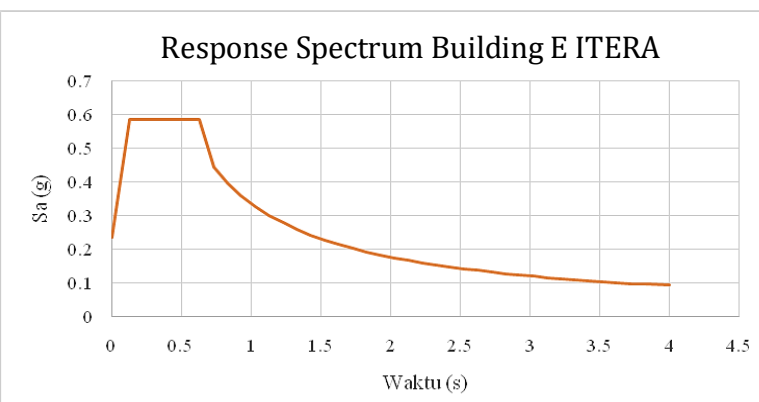

Figure 8. Response Spectrum Design Building E 


\section{b. Time History}

The earthquake load used in this study is the dynamic load of time history analysis using accelerogram. Before implementing the accelerogram series in structural analysis, the data must be scaled to reduce the mismatch between characteristics and design parameters in an area based on standards or from certain hazard sites [7]. Accelerogram is used to represent earthquake motion. The accelerogram selected in the time history analysis at the level of earthquake plan must meet the requirements as stipulated in [1] sub chapter 11.1.3.2.

From earthquakes selected records produces a picture of the characteristics of ground motion, such as magnitude, distance to the center of vibration, and site classification. The selection is usually made more emphasis on efforts to obtain records that match with the response spectrum rather than the seismological parameters. Therefore, these records are selected based on consideration of the magnitudes of a strong ground motion, such as peak ground acceleration $(\mathrm{PGA}=$ peak ground velocity), peak ground velocity (PGV = peak ground velocity), and duration in accordance with the design response spectrum [8].

The following time history data along with response spectrum that have been made to the matching process.

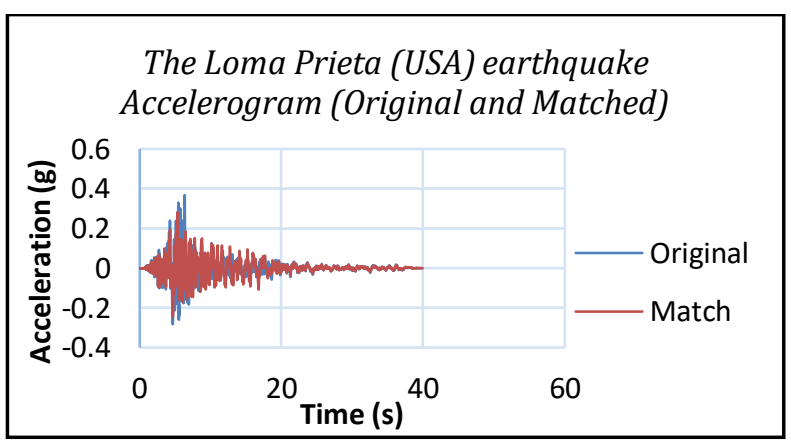

Figure 9. The Loma Prieta Earthquake Accelerogram

\section{Pounding Effect}

Collision between adjacent buildings due to a stimulus or seismic load are called the pounding effect [9]. This phenomenon has been found more than 20 years ago. A high level of complexity requires a thorough knowledge and how the building reacts if given a different magnitude but the strength of the structure remains the same. Generally, pounding categorized into floor-to-floor and floor-to-column pounding [10].

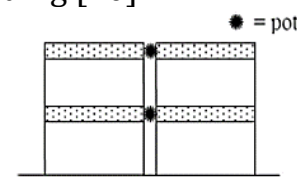

floor-to-floor

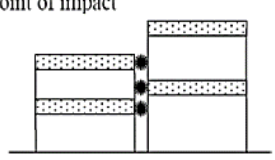

floor-to-column
Figure 10. Pounding Category [10]
The main reason for seismic pounding is the determination of the distance between buildings [11]. The response of the external forces of an adjacent building is seen from the following conditions:

a. When the gap between adjacent buildings is inadequate.

b. When the building has a separation space but is connected to one or more members.

c. When adjacent buildings have different dynamic properties such as mass, height, orientation and geometry. If the dynamic properties are similar, pounding will not occur even if the distance is zero.

d. When the center of mass of the adjacent building is not axial.

Pounding might occur due to structural irregularities [12]. For example, eccentricity between center of mass causes torque. If the structure moves regularly, there will be no collisions between adjacent buildings (Figure 11). Concrete structure have a greater risk because poor design and construction implementation.
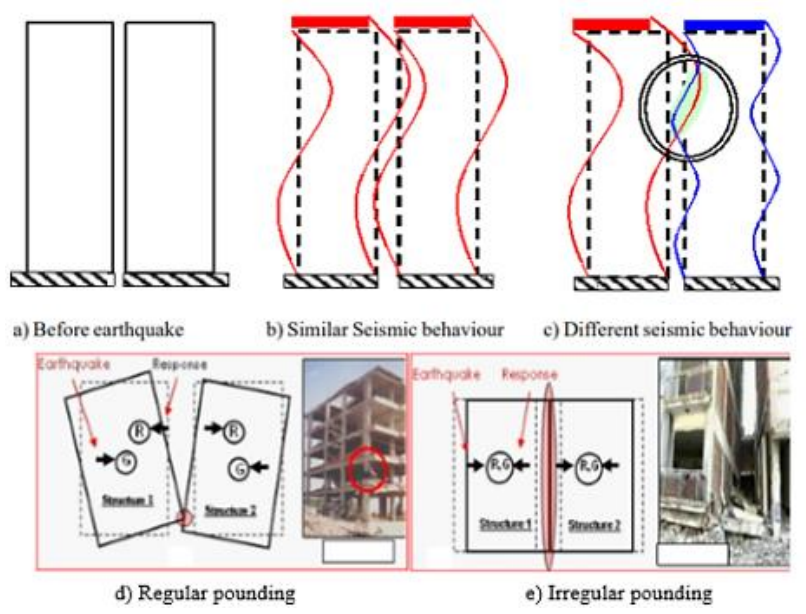

Figure 11. Seismic behaviour of adjacent buildings [12]

In accordance with regulation [13], the minimum separation distance is calculated by Absolute Sum (ABS) or Square Root of Sum of Squares (SRSS) as follows:

$$
\begin{aligned}
& \mathrm{S}=\mathrm{U}_{\mathrm{A}}+\mathrm{U}_{\mathrm{B}} \\
& S=\sqrt{\left(U_{A}^{2}+U_{B}^{2}\right)}
\end{aligned}
$$

which :

$\mathrm{S} \quad=$ separation distance

$\mathrm{U}_{\mathrm{A}}, \mathrm{U}_{\mathrm{B}}=$ displacement each building $\mathrm{A}$ and building $\mathrm{B}$.

\section{Load Combination}

Combination of loading used is the ultimate load in accordance with [4] chapter 2 as follows: 
1. $1,4 \mathrm{DL}$

2. 1,2DL +1,2 SIDL +1,6 LL+0,5 (Lr atau H)

3. 1,2DL +1,2 SIDL +1,6 ( Lr atau H) + LL

4. 1,2DL +1,2 SIDL +LL+ W+0,5(Lr atau H)

5. 1,2DL +1,2 SIDL +E +LL

6. $0,9 \mathrm{DL}+\mathrm{W}$

7. $0,9 \mathrm{DL}+\mathrm{E}$

In this study, the load combination that does not use wind and earthquake loads will remain the same, while the combination that uses wind and earthquake loads will have varying coming directions therefore creating more combinations. The combination of loading becomes as follows:

1. 1,2DL +1,2SIDL +LL+(WX+) +0,5Lr

2. 1,2DL +1,2SIDL +LL+(WX-) +0,5Lr

3. 1,2DL +1,2SIDL +LL+(WY+) +0,5Lr

4. 1,2DL +1,2SIDL +LL+ (WY-) +0,5Lr

5. 1,2DL +1,2SIDL +1ExH +0,3EyH+1EV +LL

6. 1,2DL +1,2SIDL +1ExH -0,3EyH+1EV +LL

7. 1,2DL +1,2SIDL -1ExH +0,3EyH+1EV +LL

8. 1,2DL +1,2SIDL +1EyH +0,3ExH+1EV + LL

9. 1,2DL +1,2SIDL +1EyH -0,3ExH+1EV +LL

10. 1,2DL +1,2SIDL -1EyH +0,3ExH+1EV +LL

11. $0,9 \mathrm{D}+(\mathrm{WX}+)$

12. $0,9 \mathrm{D}+(\mathrm{WX}-) 13 \cdot 0,9 \mathrm{D}+(\mathrm{WY}+)$

14. $0,9 \mathrm{D}+(\mathrm{WY}-)$

15. $0,9 \mathrm{D}+1 \mathrm{ExH}+0,3 \mathrm{EyH}+1 \mathrm{EV}$

16. $0,9 \mathrm{D}+1 \mathrm{ExH}-0,3 \mathrm{EyH}+1 \mathrm{EV}$

17. $0,9 \mathrm{D}-1 \mathrm{ExH}+0,3 \mathrm{EyH}+1 \mathrm{EV}$

18. $0,9 \mathrm{D}+1 \mathrm{EyH}+0,3 \mathrm{ExH}+1 \mathrm{EV}$

19. $0,9 \mathrm{D}+1 \mathrm{EyH}-0,3 \mathrm{ExH}+1 \mathrm{EV}$

20. $0,9 \mathrm{D}-1 \mathrm{EyH}+0,3 \mathrm{ExH}+1 \mathrm{EV}$

21. TH combination

\section{Inter-Story Drift}

Based on [1] sub chapter 7.12 .3 relating to the determination of design inter-story drift $(\Delta)$ must be calculated as the difference in deflection at the center of mass at the top and bottom levels reviewed. Deflection of the center of mass at the level $(\delta \mathrm{x})(\mathrm{mm})$ must be determined according to the following equation:

$$
\delta_{x}=\frac{C_{d} \delta_{x e}}{I_{e}}
$$

Note:

$\mathrm{C}_{\mathrm{d}}=$ deflection amplification factor

$\delta_{x e} \quad=$ deflection at the required location

determined by elastic analysis

$I_{e} \quad=$ earthquake importance factor

\section{Plastic Hinge}

Plastic hinge mechanism formed at the ends of the beam and at the base of the column produces a stable hysteresis behavior. The formation of plastic hinge should be dominated by flexural behavior. Plastic hinge can occur in a MDOF structure. Plastic hinge occurs gradually starting from forming at the ends of the beam evenly until it forms at the bottom of the column before the building collapse.

The relationship of force and displacement can be categorized into several criteria that indicate plastic hinge behavior [14]. The relationship of force and displacement can be described as Figure 12:

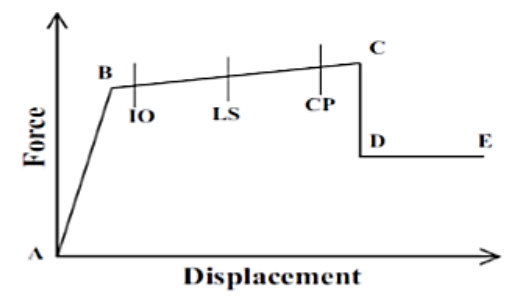

Figure 12. Plastic joint [15]

Each point determines the behavior of displacement vs force of the plastic hinge. Point $\mathrm{A}$ is the origin, $\mathrm{B}$ is the yielding point, $\mathrm{C}$ is the maximum point. $\mathrm{D}$ and $\mathrm{E}$ are measures of residual strength and displacement capacity. For the other three points namely IO, LS, and CP are structural behaviors that occur. IO (immediate occupancy) means the condition when there is no significant damage to the structure where the strength is about the same as the condition before an earthquake occurs, LS (life safety) means the condition when damage to structural components occurs, stiffness decreases, but still has sufficient threshold against collapse and CP (collapse prevention) means the condition of the occurrence of significant damage to the structural components, therefore strength of the structure is reduced significantly.

\section{RESULTS AND DISCUSSION}

\section{Matching Process}

The matching process is carried out by multiplying the Loma Prieta earthquake record with a number so that the spectrum response of the accelerogram approaches the SNI spectrum response for Lampung Province with medium soil.

The multiplication data which are acceleration and time data is drawn using the Seismosignal software so that the plot, called AGM02, can be obtained [16]. The output data from the seismosignal is an acceleration vs time data that has been adjusted to the response spectrum of Building $E$ ITERA. Comparison between spectrum response curves based on SNI and time history that has been matched can be seen in Figure 13. 


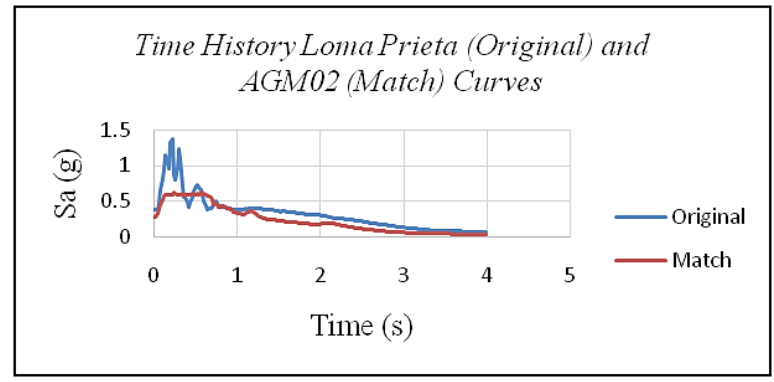

Figure 13. Time History and Response Spectrum Matching Curves

\section{Plastic Hinge}

In the process of modeling using software, auto-hinge parameters are given in each frame (beams and columns) at 0.5 and 0.95 of the length of each frame. The software output will be seen in the color indicator according to the interpretation in Figure 14.

Table 4. Structural Damage Level due to the Formation of Plastic Hinge [15]

\begin{tabular}{|c|c|c|}
\hline Note & Symbol & Commentary \\
\hline $\mathrm{B}$ & & $\begin{array}{l}\text { Shows the linear limit } \\
\text { followed by the first yield in } \\
\text { the building }\end{array}$ \\
\hline IO & & $\begin{array}{l}\text { Minor or insignificant damage } \\
\text { to the structure }\end{array}$ \\
\hline $\mathrm{LS}$ & & $\begin{array}{l}\text { Damage to moderate levels } \\
\text { cause reduced structural } \\
\text { rigidity, but still has a large } \\
\text { threshold to collapse }\end{array}$ \\
\hline $\mathrm{CP}$ & & $\begin{array}{l}\text { Severe damage to the } \\
\text { structure until the stiffness } \\
\text { was reduced significantly }\end{array}$ \\
\hline $\mathrm{C}$ & & $\begin{array}{l}\text { Maximum limit of shear force } \\
\text { that is still able to be resisted } \\
\text { by the building }\end{array}$ \\
\hline $\mathrm{D}$ & & $\begin{array}{l}\text { There is a great structural } \\
\text { strength degradation so that } \\
\text { structural condition is stable } \\
\text { and almost collapse }\end{array}$ \\
\hline $\mathrm{E}$ & & $\begin{array}{l}\text { Structure is not able to resist } \\
\text { shear force (Total failure) }\end{array}$ \\
\hline
\end{tabular}

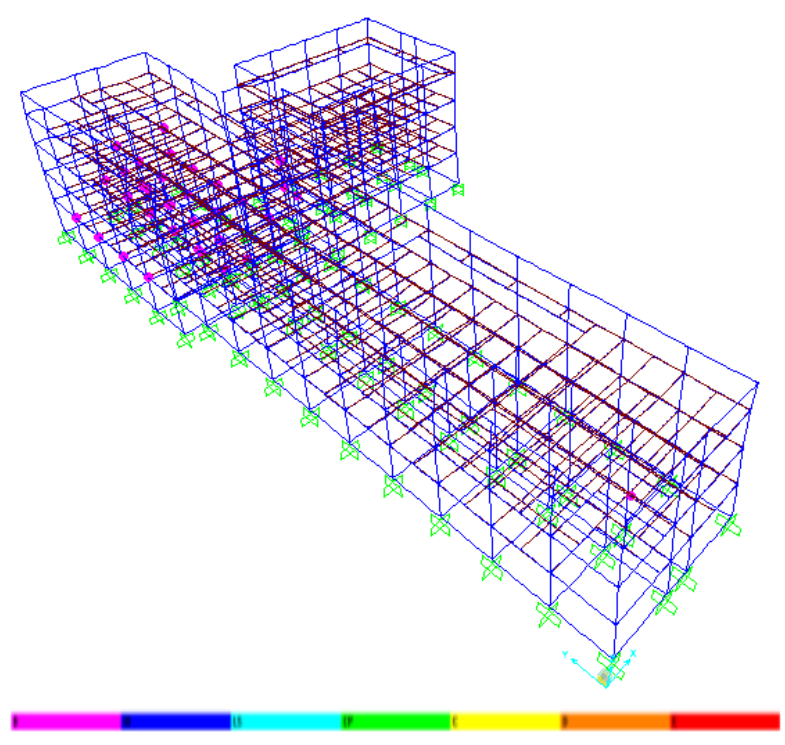

Figure 14. Plastic Hinge at Building E Caused by Loma Prieta Earthquake

Plastic hinges in Figure 14 at the last second of time history earthquake load have formed at the end of the beam (shown in pink). Therefore, the structure is still in an elastic state (point B in Figure 12 and Table 4). In other words, the structure does not suffer damage due to the earthquake load of nonlinear time history.

\section{Inter-buildings Deflection}

Three separate buildings with the concept of dilatation in building $E$ modelled in a file. Displacement analysis is at the joint in each floor that becomes a meeting between buildings. The meeting point between buildings is defined as K1 to K4 which is the meeting between Building 1 and 2, and $\mathrm{K} 5$ to K6 which is the meeting between Building 2 and 3.

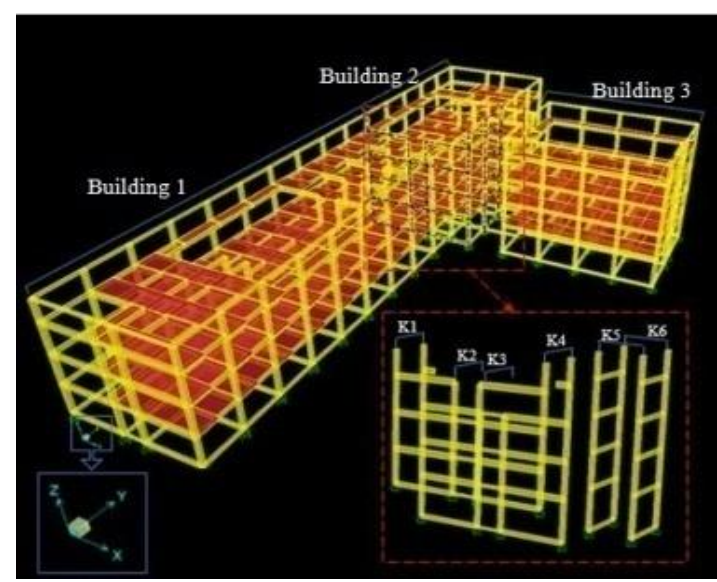

Figure 15. Meeting Points Definition Between Adjacent Buildings 
Figure 15 indicates that there are 4 meeting zones between building 1 and building 2 along the $Y$ axis, namely K1, K2, K3 and K4. Between buildings 2 and 3 towards the $\mathrm{X}$ axis, there are 2 meeting zones namely K5 and K6.

Building E ITERA consists of 3 buildings that are built close to the distance between buildings 50 $\mathrm{mm}$ from the outer side of the column or $550 \mathrm{~mm}$ from the column center line.

The inter-buildings displacement graphs (Figures 16 and 17) are adjusted to the distance in the as built drawing of Building E ITERA that is 50 $\mathrm{mm}$, so that the movement of the joint displacement can be seen. Using equation (17) the displacement value can be seen from Table 5 to Table 8 .

Table 5. Max. Displacement Loma Prieta Earthquake at Building 1 in Y Direction ( $t=4.85 \mathrm{~s})$

\begin{tabular}{|c|c|c|c|c|c|c|c|}
\hline \multicolumn{4}{|c|}{ K1 } & \multicolumn{4}{|c|}{ K3 } \\
\hline \multicolumn{2}{|c|}{ Building 2} & \multicolumn{2}{|c|}{ Building 1} & \multicolumn{2}{|c|}{ Building 2} & \multicolumn{2}{|c|}{ Building 1} \\
\hline No. Joint & $\operatorname{dy}(\mathrm{mm})$ & No. Joint & $\operatorname{dy}(\mathrm{mm})$ & No. Joint & $\operatorname{dy}(\mathrm{mm})$ & No. Joint & $\mathrm{dy}(\mathrm{mm})$ \\
\hline 542 & 2.6713 & 145 & 40.2310 & & & 157 & 38.3127 \\
\hline 375 & -3.3692 & 71 & 29.3691 & 374 & -3.1912 & 70 & 29.3762 \\
\hline 101 & -14.7334 & 43 & 13.1882 & 100 & -14.6405 & 42 & 13.2454 \\
\hline 310 & -31.4729 & 193 & 0 & 309 & -31.3882 & 223 & 0 \\
\hline 881 & -50 & & & 879 & -50 & & \\
\hline \multicolumn{4}{|c|}{ K2 } & \multicolumn{4}{|c|}{ K4 } \\
\hline \multicolumn{2}{|c|}{ Building 2} & \multicolumn{2}{|c|}{ Building 1} & \multicolumn{2}{|c|}{ Building 2} & \multicolumn{2}{|c|}{ Building 1} \\
\hline No. Joint & $\mathrm{dy}(\mathrm{mm})$ & No. Joint & $\mathrm{dy}(\mathrm{mm})$ & No. Joint & $\mathrm{dy}(\mathrm{mm})$ & No. Joint & $\mathrm{dy}(\mathrm{mm})$ \\
\hline & & 156 & 38.1779 & 559 & 3.12853 & 146 & 40.5439 \\
\hline 373 & -3.2292 & 69 & 29.3593 & 376 & -3.14582 & 72 & 29.4695 \\
\hline 99 & -14.6721 & 34 & 13.2377 & 102 & -14.5446 & 44 & 13.2337 \\
\hline 308 & -31.4069 & 222 & 0 & 311 & -31.3618 & 224 & 0 \\
\hline 880 & -50 & & & 878 & -50 & & \\
\hline
\end{tabular}

Table 6. Max. Displacement Loma Prieta Earthquake at Building 2 in Y Direction $(t=5.0 \mathrm{~s})$

K1

Building 2

\begin{tabular}{|c|c|c|c|c|c|c|c|}
\hline \multicolumn{2}{|c|}{ Building 2} & \multicolumn{2}{|c|}{ Building 1} & \multicolumn{2}{|c|}{ Building 2} & \multicolumn{2}{|c|}{ Building 1} \\
\hline No. Joint & $\mathrm{dy}(\mathrm{mm})$ & No. Joint & $\mathrm{dy}(\mathrm{mm})$ & No. Joint & $\mathrm{dy}(\mathrm{mm})$ & No. Joint & $\mathrm{dy}(\mathrm{mm})$ \\
\hline 542 & 19.7095 & 145 & 19.3978 & & & 157 & 17.5404 \\
\hline 375 & 10.4257 & 71 & 14.2918 & 374 & 11.4825 & 70 & 14.3378 \\
\hline 101 & -5.4879 & 43 & 6.5044 & 100 & -4.7497 & 42 & 6.55801 \\
\hline 310 & -27.2388 & 193 & 0 & 309 & -26.824 & 223 & 0 \\
\hline 881 & -50 & & & 879 & -50 & & \\
\hline \multicolumn{4}{|c|}{$\mathbf{K} 2$} & \multicolumn{4}{|c|}{ K4 } \\
\hline \multicolumn{2}{|c|}{ Building 2} & \multicolumn{2}{|c|}{ Building 1} & \multicolumn{2}{|c|}{ Building 2} & \multicolumn{2}{|c|}{ Building 1} \\
\hline No. Joint & $\mathrm{dy}(\mathrm{mm})$ & No. Joint & $\mathrm{dy}(\mathrm{mm})$ & No. Joint & $\mathrm{dy}(\mathrm{mm})$ & No. Joint & $\mathrm{dy}(\mathrm{mm})$ \\
\hline & -50 & 156 & 17.4302 & 559 & 22.1945 & 146 & 19.6894 \\
\hline 373 & 11.1874 & 69 & 14.3378 & 376 & 12.1919 & 72 & 14.4242 \\
\hline 99 & -4.9643 & 34 & 6.5478 & 102 & -4.2019 & 44 & 6.5655 \\
\hline 308 & -26.824 & 222 & 0 & 311 & -26.5633 & 224 & 0 \\
\hline 880 & -50 & & & 878 & -50 & & \\
\hline
\end{tabular}

There are two conditions of maximum displacement which are reviewed against the Loma Prieta earthquake load. The review are when the maximum displacement occurs in Building 1 (Table
5), and the maximum displacement occurs in Building 2 (Table 6). The maximum displacement in Building 1 occurs at 4.85 seconds of time history earthquake load, while the maximum displacement 
in building 2 occurs at the 5 seconds. The maximum displacement in Table 5 and Table 6 can be seen in
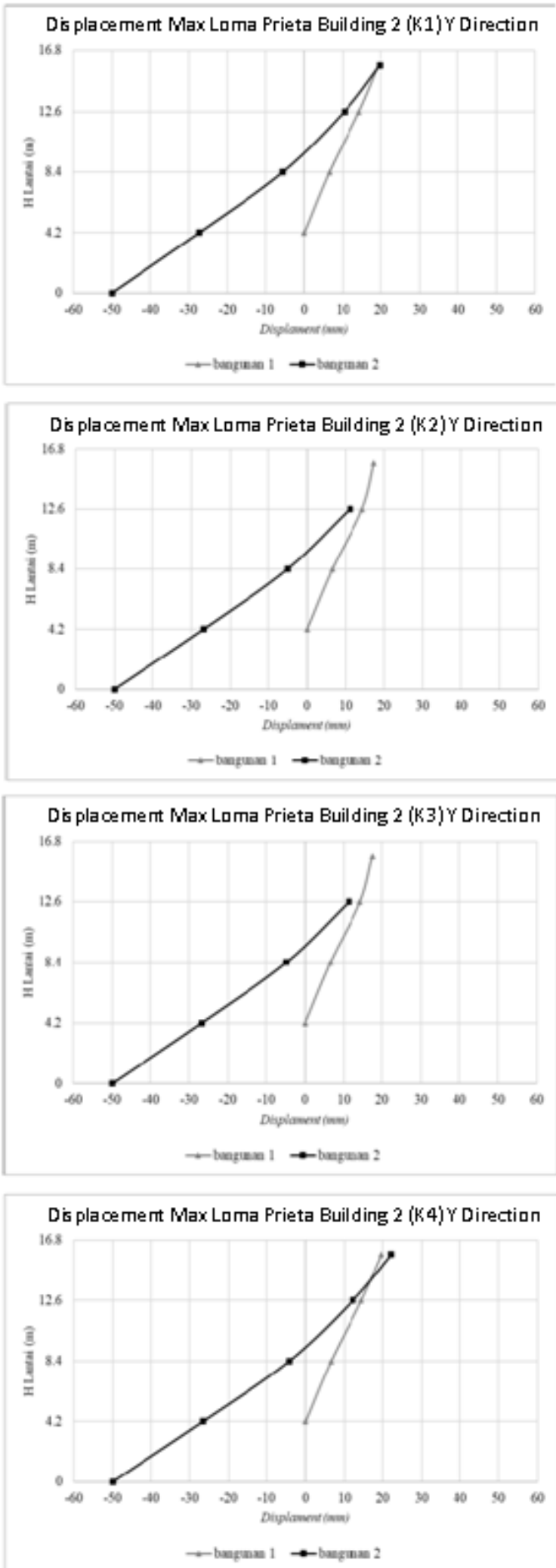

Figure 16. Displacement of Building 1-2, Loma Prieta Earthquake

Figure 16 indicates that the pounding effect occurs between Building 2 and Building 1 with the displacement difference of $0.312 \mathrm{~mm}$ in the $\mathrm{K} 1$ meeting zone in Y direction. Pounding effect also the graph in Figure 16.
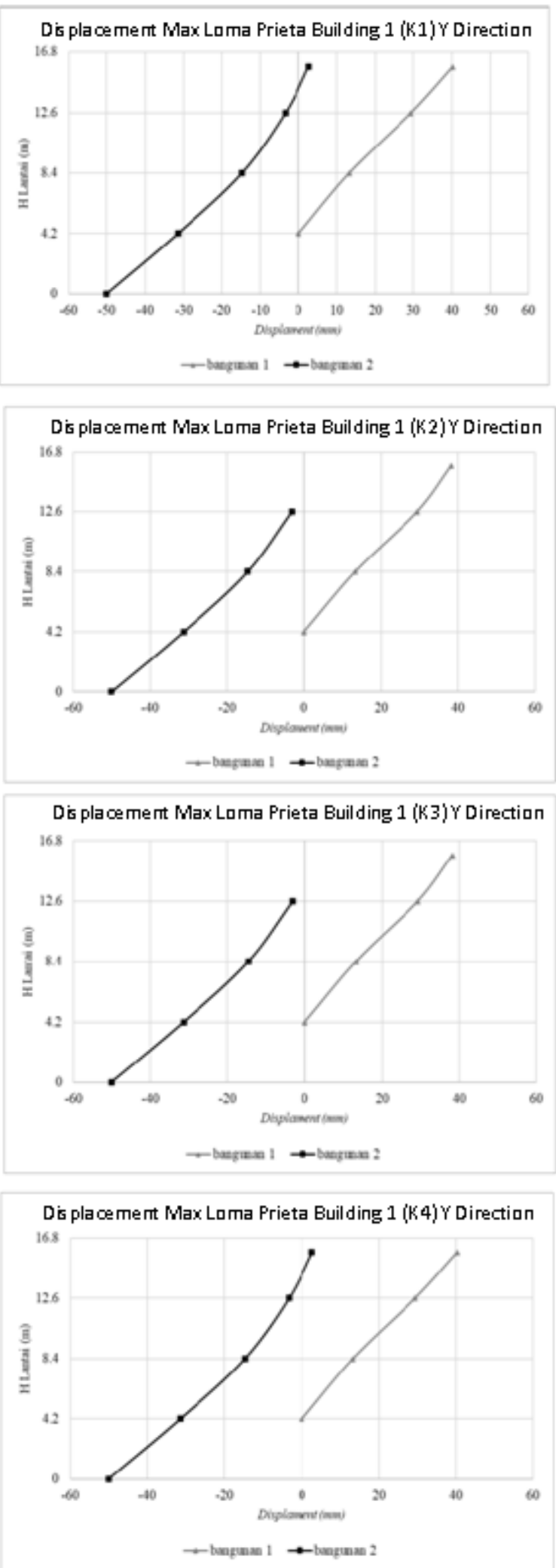

occurred between Building 2 and Building 1 with a displacement gap of $2.505 \mathrm{~mm}$ in $\mathrm{Y}$ direction at the K4 meeting zone. Both occur within 5 second of the time history earthquake load. 
Table 7. Max. Displacement Loma Prieta Earthquake at Building 2 in X Direction ( $t=4.93 \mathrm{~s})$

\begin{tabular}{rrrrrrrr}
\multicolumn{1}{c}{ K5 } & \multicolumn{6}{c}{ K6 } \\
\hline \multicolumn{2}{c}{ Building 2 } & \multicolumn{2}{c}{ Building 3 } & \multicolumn{2}{c}{ Building 2 } & \multicolumn{2}{c}{ Building 3 } \\
\hline No. Joint & $\mathrm{dx}(\mathrm{mm})$ & No. Joint & $\mathrm{dx}(\mathrm{mm})$ & No. Joint & $\mathrm{dx}(\mathrm{mm})$ & No. Joint & $\mathrm{dx}(\mathrm{mm})$ \\
\hline 557 & 1.3316 & 558 & 47.2398 & 742 & 20.6151 & 743 & 70.6151 \\
\hline 368 & -1.9376 & 372 & 46.7900 & 739 & 9.10704 & 740 & 59.1070 \\
\hline 94 & -13.8734 & 98 & 35.2519 & 729 & -7.0458 & 730 & 42.9542 \\
\hline 303 & -30.143 & 307 & 19.4451 & 736 & -28.7351 & 737 & 21.2649 \\
\hline 886 & -50 & 882 & 0 & 760 & -50 & 759 & 0 \\
\hline
\end{tabular}

Table 8. Max. Displacement Loma Prieta Earthquake at Building 3 in X Direction $(t=5.01 \mathrm{~s})$

\begin{tabular}{rrrrrrrrr}
\hline \multicolumn{4}{c}{ K5 } & \multicolumn{6}{c}{ K6 } \\
\hline \multicolumn{2}{c}{ Building 2 } & \multicolumn{2}{c}{ Building 3 } & \multicolumn{2}{c}{ Building 2 } & \multicolumn{2}{c}{ Building 3 } \\
\hline No. Joint & $\mathrm{dx}(\mathrm{mm})$ & No. Joint & $\mathrm{dx}(\mathrm{mm})$ & No. Joint & $\mathrm{dx}(\mathrm{mm})$ & No. Joint & $\mathrm{dx}(\mathrm{mm})$ \\
\hline 557 & -4.4426 & 558 & 40.8215 & 742 & 26.1755 & 743 & 76.1755 \\
\hline 368 & -6.9739 & 372 & 41.0029 & 739 & 13.5778 & 740 & 63.5778 \\
\hline 94 & -17.6051 & 98 & 30.8952 & 729 & -3.7117 & 730 & 46.2883 \\
\hline 303 & -32.0192 & 307 & 17.213 & 736 & -26.9043 & 737 & 23.0957 \\
\hline 886 & -50 & 882 & 0 & 760 & -50 & 759 & 0 \\
\hline
\end{tabular}

Similar to Table 5 and Table 6, there are two criteria under consideration for the maximum displacement of Building 2 and Building 3. The review are when the maximum displacement occurs in Building 2 (Table 7), and the maximum displacement occurs in Building 3 (Table 8). The
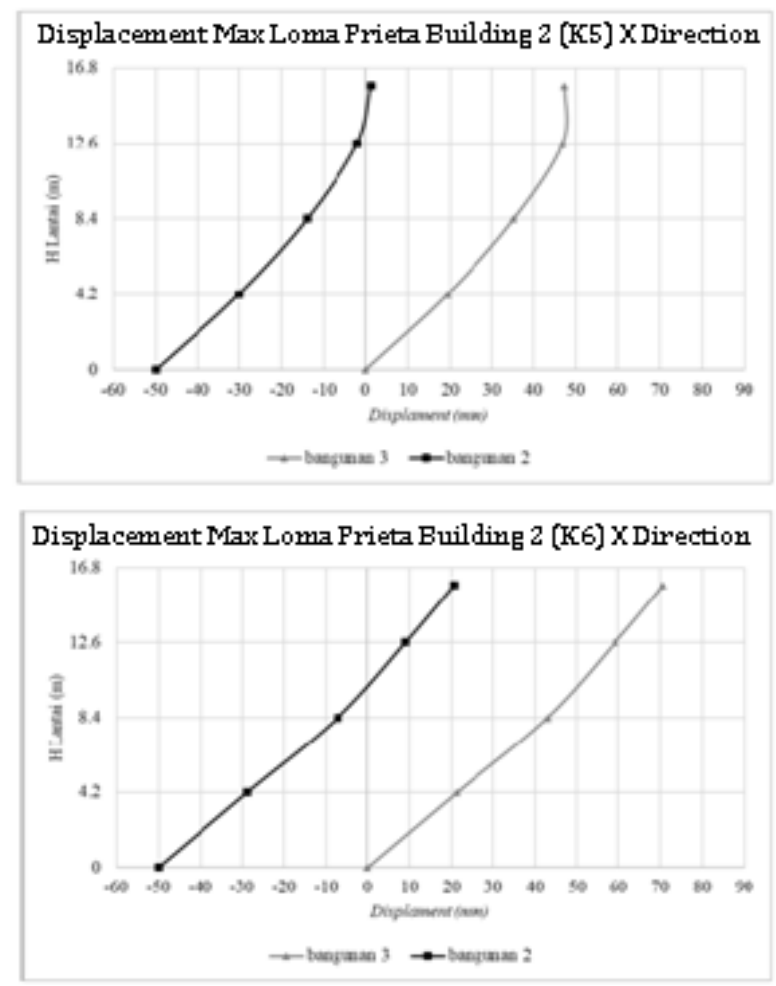

maximum displacement in Building 2 occurs at 4.93 seconds of time history earthquake load, while the maximum displacement in building 3 occurs at the 5.01 seconds. The maximum displacement in Table 7 and Table 8 can be seen in the graph in Figure 17.
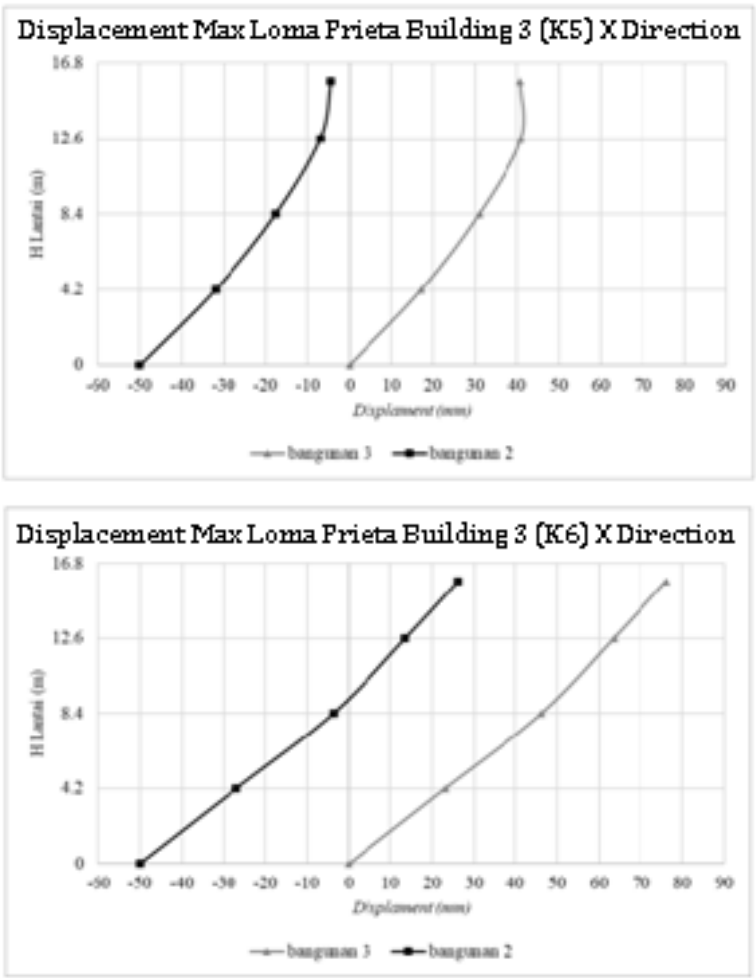

Figure 17. Displacement of Building 2-3, Loma Prieta Earthquake 
Figure 17 demonstrates that in their maximum displacement at Building 2 and Building 3 in the $\mathrm{K} 5$ and $\mathrm{K} 6$ meeting areas, there is no pounding between Building 2 and 3. The building distance of 50 $\mathrm{mm}$ is therefore secure enough.

\section{CONCLUSION}

The conclusions that can be obtained from this study are: (a) plastic hinge have been formed in Building E due to the Loma Prieta earthquake load that has been matched with the response spectrum of local area. However, the plastic hinge formed are still in the elastic limit. Hence, the structure does not suffer damage due to the earthquake load of nonlinear time history; (b) by a building spacing of $50 \mathrm{~mm}$, the pounding effect occurs at the meeting point of Buildings 1 and 2 due to the Loma Prieta earthquake load that has been matched with the response spectrum of local area. For the meeting points between Building 2 and 3 there was no pounding effect; (c) further research using earthquake record data taken in areas within certain radius from ITERA is need to be conducted to obtain more accurate results.

\section{ACKNOWLEDGMENT}

Thank you to the Ministry of Research, Technology and Higher Education which has supported the 2019 Beginner Lecturer Research Grant Program and Civil Engineering Program Study at Institut Teknologi Sumatera.

\section{REFERENCES}

[1] Badan Standardisasi Nasional, SNI 1726:2012 Tata Cara Perencanaan Ketahanan Gempa Untuk Struktur Bangunan Gedung dan Non Gedung. Jakarta: Badan Standardisasi Nasional, 2012.

[2] Edy Purwanto, Agus Supriyadi, Edy Purnomo, "Analisis Kinerja Struktur Pada Gedung Bertingkat Dengan Analisis Dinamik Respon Spektrum Menggunakan Software ETABS (Studi Kasus : Bangunan Hotel di Semarang)," e-Jurnal MATRIKS TEKNIK SIPIL, vol. 2 No. 4, pp. 569-576, December 2014.

[3] Departemen Pekerjaan Umum, Pedoman Perencanaan Pembebanan Untuk Rumah dan Gedung SKBI - 1.3.53.1987. Jakarta: Yayasan Badan Penerbit PU, 1987.

[4] Badan Standardisasi Nasional, SNI 1727:2013 Beban Minimum Untuk Perancangan Building Gedung dan Struktur Lain. Jakarta: BSN, 2013.
[5] Widodo Pawirodikromo, Analisis Dinamika Struktur, 1st ed.: Pustaka Pelajar, 2017.

[6] Pusat Studi Gempa Nasional, Peta Sumber dan Bahaya Gempa Indonesia Tahun 2017. Jakarta: Pusat Litbang Perumahan dan Pemukiman, 2017.

[7] R. Suryanita, Z. Djauhari, M. Syauqi, "Respon Struktur Portal Baja Akibat Beban Gempa Dengan Analisis Riwayat Waktu Nonlinier," Jom FTEKNIK, vol. 4, No. 2, October 2017, Available at https://jom.unri.ac.id/index.php/JOMFTEK NIK/sub chapter/view/16669/16094.

[8] Dicky Imam Wahjudi, "Pemilihan dan Penskala-an Rekaman Akselerogram Gempa Nyata agar Sesuai dengan Spektrum Respons SNI 1726-2012," Jurnal Aplikasi Teknik Sipil, vol. Vol.15, No. 2, August 2017, Available at : http://dx.doi.org/10.12962/j2579891X.v15i2.31.

[9] H. K. Chinmayi, "Study on Pounding of Structures with Soil-Structure Interaction," J. Inst. Eng. India Ser. A, vol. 100(1), pp. 199204, March 2019, Available at: https://doi.org/10.1007/s40030-018-03414.

[10] R.P. Dhakal, A.J. Carr, D.K. Bull, G.L. Cole, "Building pounding state of the art: Identifying structures vulnerable to pounding damage," in NZSEE Annual Conference, Wellington, March 26-28, 2010, pp. 1-9.

[11] Muhammad Noman, Bashir Alam, Muhammad Fahad, Khan Shahzada \& Muhammad Kamal, "Effects of pounding on adjacent buildings of varying heights during earthquake in Pakistan," Cogent Engineering, vol. 3:1, no. 1225878, pp. 1-19, Aug 2016, Available at: https://doi.org/10.1080/23311916.2016.1 225878.

[12] J D Chaitanya Kumar, M Phani Kumar, "Seismic Pounding of The Adjacent Buildings With Different Heights," International Journal of Engineering Research and Science \& Technology, vol. 4, No. 4, November 2015, Available at: http://www.ijerst.com/currentissue.php.

[13] American Society of Civil Engineers, ASCE 716 Minimum Design Loads and Associated 
Criteria for Buildings and Other Structures. Reston, Virginia, United States of America: American Society of Civil Engineers, 2017.

[14] Federal Emergency Management Agency, FEMA 356 Prestandard And Commentary For The Seismic Rehabilitation of Buildings. Washington D.C: Federal Emergency Management Agency, November 2000.

[15] Computers \& Structures, Inc., CSI Analysis Reference Manual For SAP2000, ETABS, SAFE and CSI Bridge. California: Computers \& Structures, Inc, 2016.

[16] A, Yudi, N. B. Wirawan, Bayzoni, R. Nadeak, "Analisis Perilaku Struktur Beton dan Baja Dengan Metode Levelling Time History (Studi Kasus Gedung E ITERA, Lampung, Indonesia)," Jurnal Rekayasa Sipil UB, vol. 13, No.3, pp. 173-183, 2019. 